\section{The 1906 earthquake and a century of progress in understanding earthquakes and their hazards}

\author{
Mary Lou Zoback, U.S. Geological Survey, 345 Middlefield \\ Rd., MS 977, Menlo Park, California 94025, USA
}

\section{INTRODUCTION}

At the turn of the century, San Francisco was the wealthiest and most important city on the Pacific Coast. With a population of 400,000, it was the eighth largest city in the country and the economic center of the West, largely the result of mining and railroad wealth. Then, in the early dawn of 18 April 1906, the city was rocked awake by a violent earthquake, which, together with the subsequent firestorm, reduced much of the city to ashes and ruins. The 1906 earthquake and subsequent fire remains one of the most devastating natural disasters this nation has known. At least 3000 people were killed, and in San Francisco alone, 225,000 out of the city's 400,000 residents were left homeless (Hansen and Condon, 1989). While the 1906 earthquake marked a seminal event in the history of California, it can also be remembered as the birth of modern earthquake science in the United States. It was the first time that an earthquake was recognized and documented as the result of a recurring tectonic process of strain accumulation and release. Under the leadership of Professor Andrew Lawson, of the University of California (UC)-Berkeley, teams of scientists and engineers spread across the state, carefully collecting and documenting physical phenomena related to the quake. Their exhaustive data and thoughtful conclusions, published in landmark volumes two and four years after the earthquake, together with a complementary report published by the U.S. Geological Survey (USGS) in 1907, led to a number of new discoveries about the cause and effects of earthquakes. These discoveries underlie much of modern seismic hazard analysis.

Keywords: San Andreas fault, 1906 earthquake, elastic rebound, seismic hazard, strike-slip faulting.

\section{EARLY EARTHQUAKE HISTORY}

Our knowledge of the earliest historic earthquakes in the San Francisco Bay area comes from Spanish mission records, dating back to the founding of Mission Dolores in San Francisco in 1776. The Padres reported on earthquakes damaging their missions, but this record becomes spotty with secularization beginning in the 1830s. After the Gold Rush, numerous newspapers around the region provided excellent coverage.

The historical records indicate that the latter two-thirds of the nineteenth century was a period of intense seismic activity throughout the greater San Francisco Bay area (Fig. 1). In fact, 18 magnitude 6.0 or larger earthquakes occurred in the
70 years prior to 1906, averaging one about every four years (Bakun, 1999, 2000). Significant earthquakes in this period include a magnitude 6.8-7.4 earthquake on the San Francisco peninsula in 1838, probably on the San Andreas fault (Toppozada and Borchardt, 1998; Bakun, 1999); a magnitude 6.9-7.0 event on the Hayward fault in 1868 that killed more than 35 people across the region and caused significant damage both in East Bay towns and in San Francisco (Yu and Segall, 1996; Bakun, 1999); and a magnitude $~ 6.8$ event north of Point Arena, possibly on the offshore portion of the San Andreas fault (Bakun, 2000).

Earthquakes seemed to be accepted as a nuisance but part of daily life in the region. On 12 December 1904, Andrew Lawson wrote in The Daily Californian, the UC-Berkeley newspaper, "History and records show that earthquakes in this locality have never been of a violent nature, as so far as I can judge from the nature of recent disturbances and from accounts of past occurrences there is not occasion for alarm at present" (in Fradkin, 2005, p. 25).

\section{THE SHOCK RECORDED AROUND THE WORLD}

At 5:12 a.m. on 18 April 1906, San Francisco residents were awakened variously by a strong jolt or a large roar. Stumbling from their beds, many were unable to stand as the floor and their buildings began to shake violently. Originating from an epicenter offshore from San Francisco, the earthquake ruptured the San Andreas fault in two directions, to the NW and SE, and strongly shook all of coastal northern California. Careful observers reported strong shaking lasting for 45-60 s. Many reliable observers also reported two strong pulses of shaking separated by 25-30 s (probably subevents of the large rupture). The earthquake was recorded on six local seismometers and on 90 stations around the world, part of a growing global seismic network. The next day, the New York Times featured on its front page a seismogram of the 1906 earthquake as recorded at the State Museum in Albany, New York.

The earthquake struck without warning. There was no unusual seismic activity noted in the days, weeks, and months preceding the 1906 earthquake (Gilbert, 1907, p. 16). However, astute local observers did report shaking believed to be related to a foreshock occurring $\sim 30 \mathrm{~s}$ before the main shock (Bolt, 1968; Lomax, 2005).

Within minutes of the end of shaking, fires broke out around the city of San Francisco. As is reported in a number of recent books, ruptured water lines, unseasonably warm temperatures, and the use of explosives helped create and fuel a firestorm that raged for three days; intense winds were generated as air rushed in to feed the inferno, which burned with temperatures in excess of $2000^{\circ} \mathrm{F}$. When the fires were finally out, more than 28,000 buildings had been destroyed, with some estimates attributing $80 \%-85 \%$ of the damage in San Francisco to the fire.

\section{WHEN THE SHAKING STOPPED-BIRTH OF MODERN EARTHQUAKE SCIENCE IN THE UNITED STATES}

One of leading geologists of his time and a former chief geologist of the USGS, Grove Karl Gilbert was visiting UCBerkeley in April 1906, studying the effects of hydraulic min- 


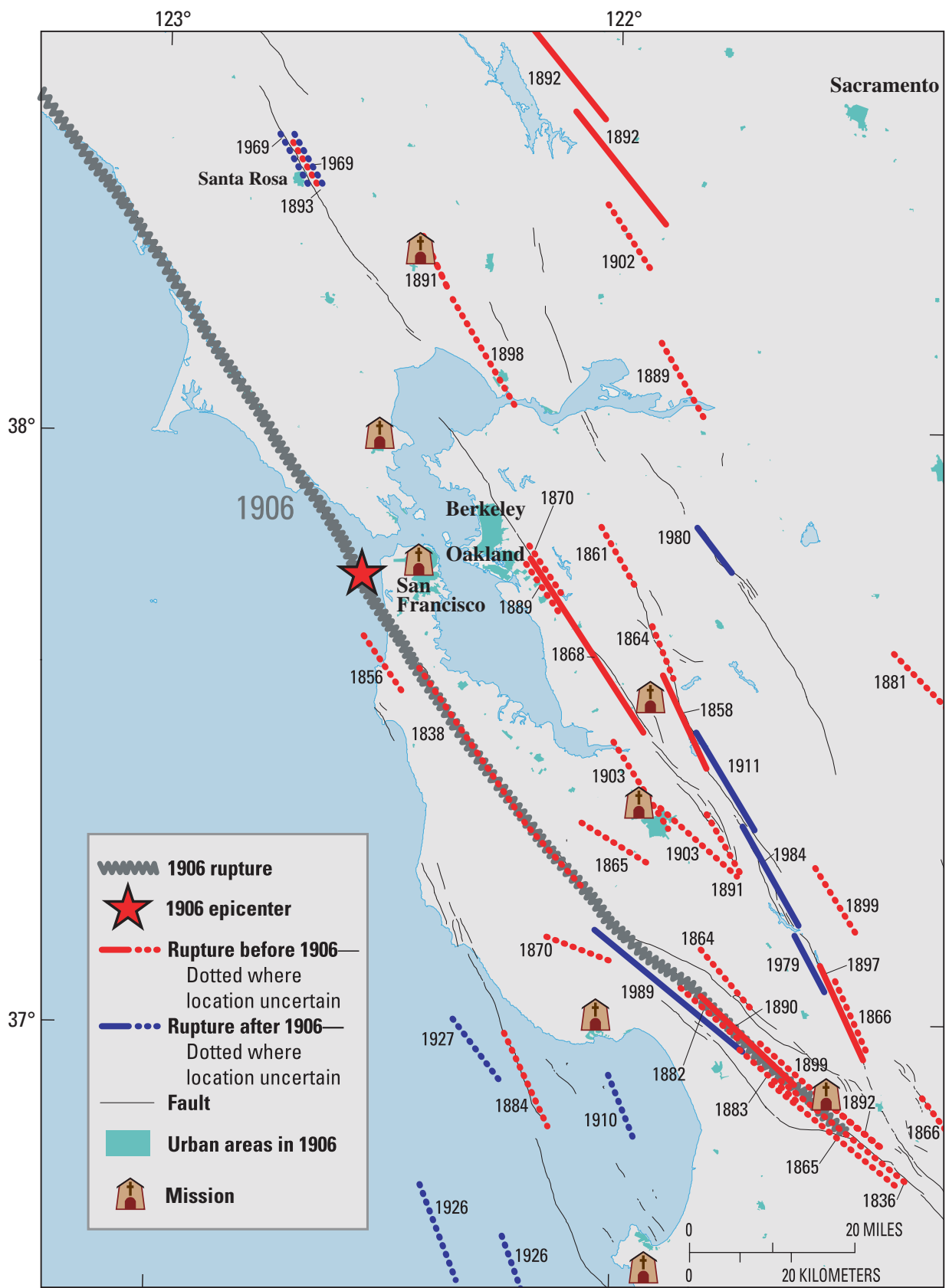

Figure 1. Rupture zones of moderate to large earthquakes $(M \geq 5.5$ ? $)$ in the San Francisco Bay region over the past $170 \mathrm{yr}$ based on earthquake locations from Toppozada et al. (1981) and Bakun (1998). 1906 rupture shown by the bold black wavy line; epicenter by star (after Lomax, 2005). Rupture zones in red are for earthquakes prior to 1906; in blue for earthquakes after 1906. Solid linesconstrained rupture zones located from surface breaks, aftershock studies, or inferred by Bakun (1998) in an analysis of historic intensity data. Dotted rupture lines—drawn parallel to local fault trends, their position and lengths (scaled to magnitude) based on Bakun (1999).

ing on San Francisco Bay. His reaction to the quake was probably typical of that of a number of scientists and engineers in the area. "When, therefore, I was awakened in Berkeley on the eighteenth of April last by a tumult of motions and noises, it was with unalloyed pleasure that I became aware that a vigorous earthquake was in progress" (in Wallace, 1980, p. 41).

Three days after the earthquake, California Governor George C. Pardee appointed an eight-person Earthquake Investigation Commission in response to a request by Andrew Lawson. As requested by Lawson, the commission would work without pay, requiring only field expenses that were ultimately raised from the Carnegie Institution (who also published the final report). Lawson led the commission and oversaw the work of more than 25 geologists, seismologists, geodesists, biologists, and engineers, as well as some 300 others who contributed to the effort (Prentice, 1999).

The commission published a preliminary 17-page report on 31 May 1906. Their main report, The Report of the State Earthquake Investigation Commission, volume I, was edited by Lawson and published in 1908. It included the bulk of the geologic and morphological descriptions of the faulting, detailed reports on shaking intensity, as well as an impressive atlas of 40 oversized maps and folios. A second volume, edited by Henry Fielding Reid and published in 1910, focused on the seismological and mechanical aspects of the quake. Hereafter in this text, The Report of the State Earthquake Investigation Commission (both volumes: v. I, Lawson, 
1908, and v. II, Reid, 1910; 643 pages total) will be referred to as the Commission Report, with the volume number noted as appropriate. The report is still available today in print and online (see references).

The commission was relentless in systematically reporting all manner of data about the earthquake. They included more than 310 photographs and numerous sketches capturing details of the surface rupture, offset culture features, and the nature and style of damage to buildings and other structures. In addition to documenting the earthquake, they also conducted simple laboratory experiments and mathematical analyses to help them understand some of their puzzling observations. In the end, their thoughtful interpretation of all these data, models, and analyses lead to a number of firstorder discoveries about the earthquake and its effects.

\section{Recognizing the San Andreas Fault as a Continuous Geologic Feature}

The Commission Report (v. I) contains the first integrated description of the San Andreas fault. Small sections had previously been mapped and described (in 1895, Lawson had mapped and named a few miles of the fault on the San Francisco peninsula after the San Andreas Valley in which it was contained), but the earthquake rupture demonstrated the continuity of the structure. The location and morphology of the fault zone are described in detail and depicted on numerous large-scale maps along the $\sim 220 \mathrm{~km}$ onshore portion of the surface rupture. One commission member, H.W. Fairbanks, continued mapping the San Andreas fault southeast of the 1906 rupture all the way to Southern California, southeast of San Bernardino, connecting the 1906 rupture to the same fault as the still relatively fresh rupture from the 1857 magnitude 7.8 earthquake in Southern California. The Commission thus established the San Andreas fault as a continuous geologic structure extending for over 600 miles throughout much of California.

\section{Establishing the Movement on the Fault as Strike-Slip}

By documenting the offset of fences, roads, rows of trees, and other cultural features, the commission geologists reported commonly between 8 and $15 \mathrm{ft}$ (and locally up to $21 \mathrm{ft}$ ) of horizontal slip during the earthquake. They also noted that the offsets north of the Golden Gate were generally greater than those to the south on the San Francisco peninsula. Gilbert (1907) reported associated vertical offsets that were "minor and of variable amount." The significance of this large horizontal offset remained problematic for decades. As Prentice (1999) noted, most scientists (including many of the contributors to the 1908 report) did not consider horizontal slip to be a geologically important mode of fault movement. This is not surprising because gravity provided an obvious source of vertical forces but there was no known source of large-scale horizontal forces until the theory of plate tectonics was established many decades later. Wallace (1949) was the first to suggest substantial $(>120 \mathrm{~km}$ ) right-lateral offset along the San Andreas fault. In a landmark paper, Hill and Dibblee (1953) suggested several hundred kilometers of right-lateral displacement of geologic units and also showed that older units were offset more than younger units.

\section{Inferring Earthquake Recurrence from Evidence of Similar Past Movements}

In addition to documenting the width of and offset along the rupture zone, commission geologists noted small-scale linear ridges and valleys lying within and striking parallel to the fault zone. Gilbert, in particular, grasped the significance of these topographic features, commenting, "It is easy to understand that the inception as well as the perpetuation of the ridges and valleys was due to faulting" (v. I, p. 33). He further noted that "the surface changes associated with the earthquake tended, within this belt, to increase the differentiation of the land into ridges and valleys," thus establishing the evidence for repeated recent earthquakes along the fault. These observations expanded on his conclusions of recurring earthquakes along the Wasatch fault zone in Utah based on repeated vertical offsets of Lake Bonneville shorelines (Gilbert, 1884) and provided the foundation for the modern field of tectonic geomorphology (Prentice, 1999).

In its summary section (v. I, p. 53), the Commission Report concluded, "The successive movements which in the past have given rise to the peculiar geomorphic features of the Rift ... have with little question been attended in every case by an earthquake of greater or less violence. The earthquake of April 18, 1906, was due to a recurrence of movement along this line." (Note: Because the fault was often contained within a linear, well-defined 0.8-1.6-km-wide valley, the report commonly refers to the fault zone as the San Andreas Rift.) The commission members' attention to detail and confidence in the recurrence of such events led them to establish two small arrays "for measurement of future movements on the San Andreas fault" (v. I, p. 152).

\section{Proposing the Elastic Rebound Theory and Basis for the "Earthquake Cycle"}

One of the most profound findings from the commission investigation came from analysis of a relatively new and unexplored data set-distortion of the triangulation surveying network. J.F. Hayes and A.L. Baldwin of the U.S. Coast and Geodetic Survey resurveyed much of the northern California triangulation network in the 15 months after the earthquake. Their careful analysis (v. I, p. 114-145) documented evidence for displacements in both the 1868 Hayward fault earthquake and the 1906 quake. For 1906, they found that coseismic horizontal displacements were approximately parallel to the San Andreas fault, with points on opposite sides of the fault moving in opposite directions, consistent with the observed right-lateral offsets. They further concluded that the magnitude of the displacements decreased in a nonlinear fashion away from the fault, with the displacement decreasing most rapidly near the fault (Fig. 2).

H.F. Reid, in vol. II of the Commission Report, grasped the significance of the geodetic data on coseismic displacement as well as the evidence for distant pre-earthquake displacements. He inferred that the nearly instantaneous fault slip during the quake represented release, or "elastic rebound," of distant applied external elastic forces (Reid, 1910, p. 17) (Fig. 2). Reid went on to explore his theory with experiments in which he deformed, in shear, a layer of stiff jelly with a fault cut through it. He showed that shear displacements of the 

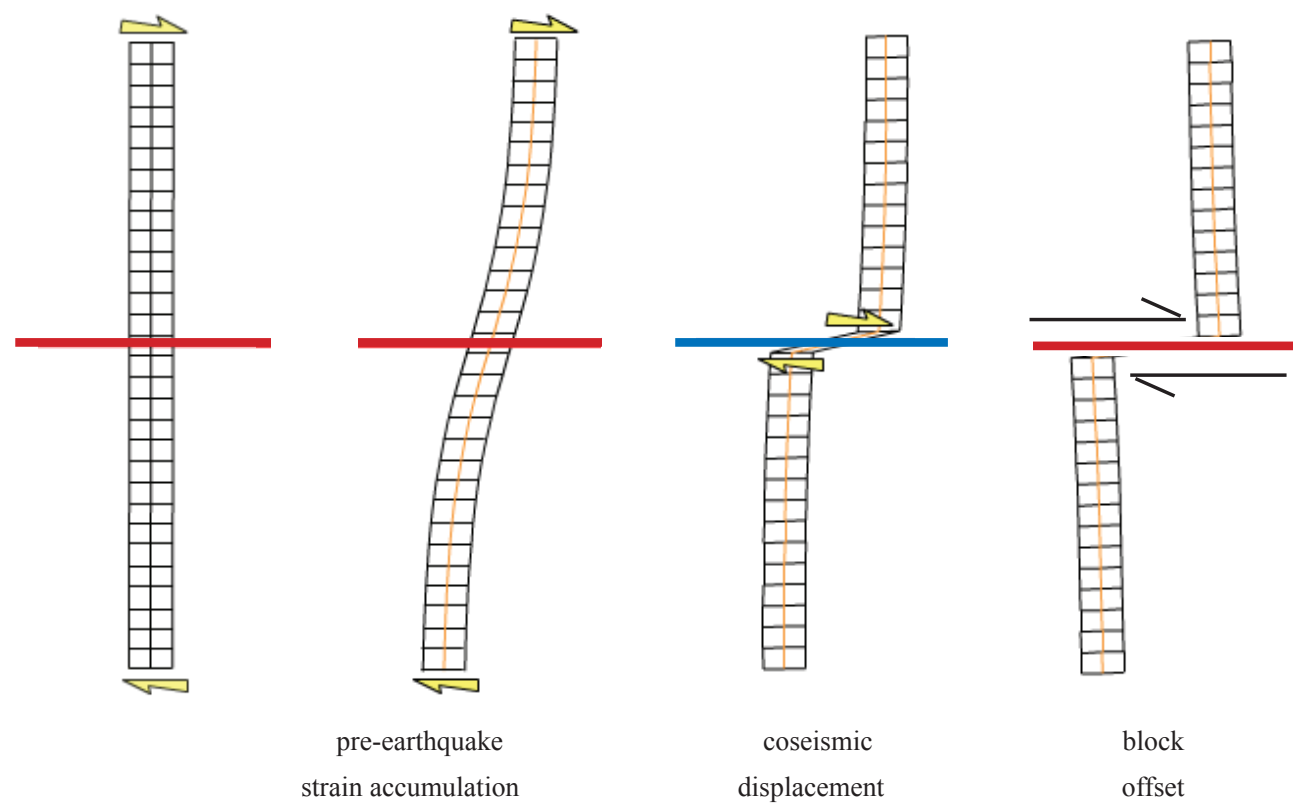

Figure 2. Elastic rebound hypothesis after Reid (1910). Fence indicates a line across the fault extending 100+ km on either side.

edge of the jelly block loaded the "fault," and when the fault was allowed to slip, the strain was relieved and the net result was block displacement.

No doubt influenced by Gilbert's and others' geomorphic evidence for repeated faulting, Reid envisioned the strain accumulation and release as a recurring process. He proposed the now famous "elastic rebound hypothesis" to explain the earthquake cycle-that earthquakes represent sudden release of elastic energy along a fault resulting from a long period of slow strain accumulation. This hypothesis is still accepted today, even though the basis for large-scale horizontal displacements wasn't established until the plate tectonic revolution more than 50 years later.

\section{Correlating Shaking Intensity to Geology}

The commission's attention to geologic and geomorphic phenomena was matched by their detailed descriptions of the damage caused by the earthquake. They documented the extent and style of damage to all manner of buildings, dams, pipelines, and other structures. In addition, they reported the distribution and direction of motion of damaged chimneys, broken-off headstones, and even the direction that milk sloshed out of pails. Through interviews and combing newspaper and personal accounts, they compiled damage and shaking reports for more than 600 sites, demonstrating strong shaking throughout nearly all of the northern California Coast Ranges and revealing that the earthquake was felt into southern Oregon and as far east as central Nevada. Their damage reports remain the largest set of seismic intensities ever compiled for a single earthquake and recently were utilized to construct a modern "Intensity ShakeMap" for the 1906 earthquake, which can be compared to maps made of shaking intensity based on measured values, such as for the 1989 Loma Prieta earthquake (Boatwright and Bundock, 2004).
The commission's first-order observation from the damage reports was, not surprisingly, that shaking intensity generally decayed with distance from the fault. However, a detailed examination of damage in San Francisco corroborated observations elsewhere and indicated a strong correlation between surface geology and shaking intensity. H.O. Woods (v. I) compiled a detailed $(1: 24,000)$ intensity map for San Francisco, defining five intensity zones to which he assigned approximate ground accelerations by comparison to a calibrated Japanese seismic intensity scale. This was an amazing accomplishment considering the earthquake damage had to be sorted out from the far more pervasive and devastating fire damage. Comparison of Woods' map with a geologic map of San Francisco compiled by Andrew Lawson revealed that "the amount of damage produced by the earthquake ... depended chiefly on the geological character of the ground," that the "areas that suffered most severely were those upon filled ground," and "areas upon marshy ground showed destructive effects similar to artificial filled land" (v. I, p. 252).

To explore the observation that shaking intensity was stronger on soft ground than on rock at comparable distances from the fault, H.G. Rogers (v. I, p. 326-335) designed an ingenious set of experiments measuring the amplitude of shaking of sand in a vibrating box. Cognizant of possible scale and edge effects in such experiments, Rogers showed that at seismic frequencies, the amplitude of motion of soft, waterfilled sediments is generally greater than that in surrounding rock. Using mathematical analysis to extend the application of these experiments, Reid (v. II, p. 54) correctly concluded that the response of basins depended on their size relative to the wavelength of the seismic waves and that in large basins, internal reflections could result in increased amplification. He further suggested that variations in amplitude within and 
between large basins were related to "differences in the character and depth of the alluvium" (v. II, p. 56).

\section{Relating Damage to Construction Style and Quality}

The engineers on the commission, as well as those writing for the complementary USGS Bulletin (see Humphrey, 1907), quickly recognized several principles. The first was that wellconstructed, tall steel frame buildings (generally commercial buildings built by private companies) performed quite well during the earthquake, particularly those with steel work that was well braced in the lower floors (Humphrey, 1907). A second principle was the "value of deep piling as a foundation structure in made land." Despite the stronger shaking intensity in soft soils, they noted that cable car tracks (underpinned by deep pilings) were often all that remained passable (and served as sidewalks) on many streets destroyed by liquefaction. Similarly, they reported that "first-class modern buildings" on made land "built upon deep piling and grillage formations were not imperiled by injuries to their walls or framework" (v. I, p. 235).

Those positive outcomes were tempered by the recognition that much of the building damage could be related to poor construction practices. The Mining and Scientific Press, in its 28 April 1906 edition (in Fradkin, 2005, p. 23), noted that "the amount of dishonest construction that escapes undetected in a big city is appalling and it is this that the earthquake, like a relentless inspector, exposes." Humphrey (1907) documented a number of faulty construction practices such as "collapse due to lack of tie between wall and frame" and "light wooden framing, insufficient bracing and poor mortar." Both reports noted numerous examples of the peril of unreinforced masonry as well as brick or stone building façades. Sadly, this same story of poor construction practices-resulting in catastrophic damage and collapse-has oft been repeated in a number of recent large urban earthquakes, even in countries with supposedly modern building codes.

\section{STILL REAPING REWARDS FROM THE COMMISSION REPORT}

Nearly one hundred years after its publication, the Commission Report remains a model for post-earthquake investigations. Because the diverse data sets were so complete and carefully documented, researchers continue to apply modern analysis techniques to learn from the 1906 earthquake.

\section{Seismological Data}

Modern seismology was in its infancy at the time of the 1906 earthquake. The first modern seismometers developed out of a collaboration of three British scientists (Ewing, Gray, and Milne) at the Imperial College in Tokyo, Japan, in the early 1880s (Dewey and Byerly, 1969). In 1887, astronomers brought the first two seismometers in the Western Hemisphere to the Bay Area to track earth movements that might introduce astronomical errors, and on 19 August of that year, the first local earthquake was recorded in the Bay Area (Fradkin, 2005). Most of the seismometers in operation locally at the time of the 1906 earthquake were duplex pendulum seismometers that were not sufficiently damped and almost immediately went off-scale (Reid, 1910). The only instrument that stayed on-scale, an Ewing three-component seismograph at Lick Observatory, produced the first-ever "strong motion" record of a large earthquake (Bolt, 1968). Fortunately, the commission reported station and instrument data as well as arrival times for the six local and 90 other stations that recorded the 1906 earthquake. They obtained 72 of these seismograms and reproduced them in the Commission Report, preserving them for future examination and analysis.

The 1906 earthquake is often referred to as having a "Richter magnitude" of 8.3 (Richter, 1958, p. 340). However, the Richter magnitude scale was developed for local earthquakes recorded on high-frequency seismometers. The preferred descriptor for large earthquakes rich in low frequencies is moment magnitude $\left(M_{W}\right)$. This magnitude is directly proportional to energy release and can be obtained from analysis of broad-spectrum seismograms or from the product of the rupture area and average fault slip. Modern analyses suggest a $M_{\mathbb{W}}$ between 7.7 and 7.9 for the 1906 earthquake (Wald et al., 1993; Thatcher et al., 1997). Each unit step in $M_{W}$ is equivalent to roughly a factor of 32 in energy release; thus, it would require roughly thirty 1989 $\mathrm{M}_{\mathbb{W}}=6.9$ Loma Prieta earthquakes occurring simultaneously to equal the energy release of the 1906 event.

In 1969, Bruce Bolt interpreted some of the teleseismic records and the local observations contained in the Commission Report using modern techniques to show that the epicenter was most likely offshore of Daly City, rather than near Olema as Reid had concluded in 1910. (Reid had used crude estimates of seismic wave velocities and probably misidentified the phase that stopped clocks). Boore (1977) interpreted the "strong motion record" from Mount Hamilton and concluded an epicenter offshore in the Golden Gate region best matched that data. Recently, Lomax (2005) combined modern analysis using three-dimensional velocity models with a grid-search algorithm of possible locations (to account for the imprecision of the observations). His maximum likelihood solution was in the region offshore of the Golden Gate. Constraining the epicenter to fall on the mapped fault offshore yields a "best estimate hypocenter" of $37.75^{\circ},-122.55^{\circ}$, and a depth of $10 \pm 2$ $\mathrm{km}$ with a horizontal uncertainty of $\pm 4 \mathrm{~km}$ (Fig. 1).

\section{Inferred Fault Length and Slip}

In 1975, Thatcher reanalyzed the original triangulation surveying records used in the Commission Report and determined variable amounts of slip at depth along the 1906 rupture averaging 4-5 $\mathrm{m}$ north of the Golden Gate and 2-3 $\mathrm{m}$ to the south. Using some previously unexamined regional geodetic networks, Thatcher et al. (1997) refined the slip distribution for 1906. They determined slip along 10-km patches along the San Andreas fault where data were available and interpolated slip values for the patches in between; the resulting pattern of slip is in good agreement with the measured surface offsets (Fig. 3). Significantly, they concluded that the rupture extended all the way to Cape Mendocino through the offshore segment of the San Andreas fault north of Point Arena, for a total rupture length of $477 \mathrm{~km}$. In fact, they interpreted that some of the largest slip occurred at this northernmost end, but noted large uncertainties in that region. This northerly extension of the 1906 rupture is compatible with the seismic intensity distribution as well as reports of possible surface slip near Point Delgado. 


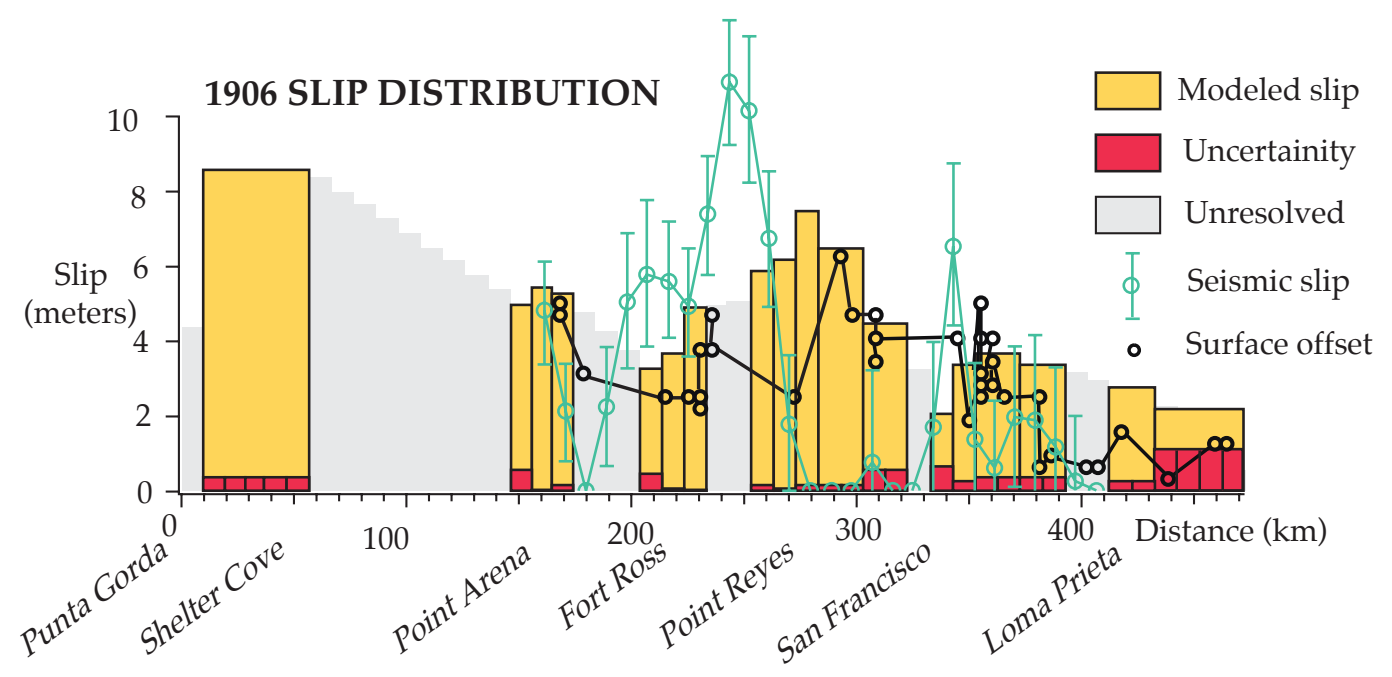

Figure 3. Comparison of slip distributions for the 1906 earthquake from surface offset measurements (Lawson, 1908), analysis of geodetic networks (Thatcher et al., 1997), and inversion of teleseismic data (Wald et al., 1993).

Also plotted in Figure 3 are the results of an inversion for fault slip by Wald et al. (1991, 1993) using the teleseisms from the Commission Report. There is a rather poor agreement between this seismic inversion and the geodetic inversion for slip. Recently, Song et al. (2005) suggested this discrepancy may be explained by a supershear rupture velocity, possibly as high as $5 \mathrm{~km} / \mathrm{s}$.

\section{A CENTURY OF PROGRESS IN UNDERSTANDING EARTHQUAKES AND THEIR EFFECTS}

The knowledge and understanding that came out of the study of the 1906 earthquake established several principles that underlie modern seismic hazard assessment:

- The earthquake was associated with a long, continuous "active" fault that exhibited ample evidence of past earthquakes with similar-style fault offsets.

- $\quad$ Earthquake occurrence was attributed to a cycle of longterm elastic strain accumulation and sudden release.

- Earthquake ground motion was found to generally decrease with distance from the fault and vary according to the character of near-surface materials as well as local structure, such as in large, deep basins.

Over the past century, new data and techniques have enabled us to quantify and refine these principles. Modern seismic networks accurately locate earthquakes to help identify active faults, while seismometers with wide dynamic range are recording, on-scale, both weak and strong ground motion. Modern analysis of the broadband seismic data are yielding key insights into the nature of the earthquake source as well as the parameters that most influence damaging shaking levels in earthquakes. For example, Wald et al. (1993) used modern earthquakes as analogs to model 1906 teleseismic data. They proposed a large asperity (source of strong seismic radiation) along the 1906 rupture to explain extremely high shaking intensity extending from the San Andreas fault into the town of Santa Rosa, $40 \mathrm{~km}$ from the fault and the site of the greatest 1906 earthquake damage per capita (Humphrey, 1907).
In the 1970s, the USGS pioneered advanced surveying techniques to establish the localization and rates of strain accumulation along the San Andreas fault system. Today, strain data are collected by many groups using global positioning satellite receivers accurate enough to resolve long-term horizontal strain accumulation rates of several centimeters per year within only a few months of continuous observations.

The pioneering papers of Clark et al. (1972), Bonilla (1973), Sieh (1978), and Swan et al. (1980) demonstrated that the timing of past earthquakes could be constrained by dating of disrupted soil layers exposed in trenches across active faults. These data establish "recurrence intervals" for surface-rupturing earthquakes (generally magnitude $\sim 6.5$ and greater). Dating of offset channels and other geomorphic features yield long-term slip rates on active faults averaged over thousands of years. In some cases, these geologic slip rates agree well with geodetically determined strain accumulation rates. In other cases, there are large discrepancies, suggesting changes in rates over time and/or possible clustering behavior.

Geologic, seismic, and geodetic data provide key inputs into the first step in assessing seismic hazard of a region-source characterization, in which the active faults are identified and the likely magnitude and mean recurrence intervals for earthquakes on them are determined. Earthquake probabilities, or forecasts, are then developed by applying statistical models of the earthquake cycle and summing over all possible earthquake sources within a prescribed region. The probability calculation can be done in a time-independent manner, assuming average long-term, average occurrence rates; or, it can be done in a time-dependent fashion, in which the position within the earthquake cycle on each fault is taken into account by including the time since the most recent event on the fault. The Working Group on California Earthquake Probabilities issued their first "earthquake forecast" in 1988 based on these principles. A current time-dependent earthquake forecast for the San Francisco Bay area, shown in Figure 4 (Working Group on California Earthquake Probabilities, 2003), indicates that at 
least one damaging earthquake $\left(\mathrm{M}_{\mathrm{W}} \geq 6.7\right)$ is nearly twice as likely as not to occur in the region over the next 30 years. This forecast integrates data on earthquake sources and strain loading in the Bay Area and allows for a range of earthquake sizes that rupture one or more identified segments of the major fault systems, as well as "background" earthquakes occurring off the main faults.

One of the most significant tectonic legacies of the 1906 earthquake was the "silencing" of seismicity throughout the San Francisco Bay region-undoubtedly a factor favoring the intense development and tenfold population increase of the region during the twentieth century. As previously noted, the relative seismic quiescence of the twentieth century is in marked contrast to the 70-year interval leading up to the 1906 earthquake (Fig. 1). The post-1906 suppression of seismicity on Bay Area faults is attributed to a "stress shadow" effect-the large slip on the San Andreas fault in 1906 reduced the Coulomb failure stress on all the surrounding parallel faults (Ellsworth et al., 1981; Harris and Simpson, 1998). The occurrence of moderate-sized earthquakes beginning in the late 1960s and including the 1989 Loma Prieta event suggests that the region has begun to emerge from the stress shadow as tectonic strain has reaccumulated slip to overcome the stress reductions. Uncertainty in the earthquake forecast (Fig. 4) reflects uncertainties in modeling the exact magnitude and duration of the stress shadow.

Modern seismic hazard assessments compute the expected earthquake shaking intensity levels within a region by integrat-

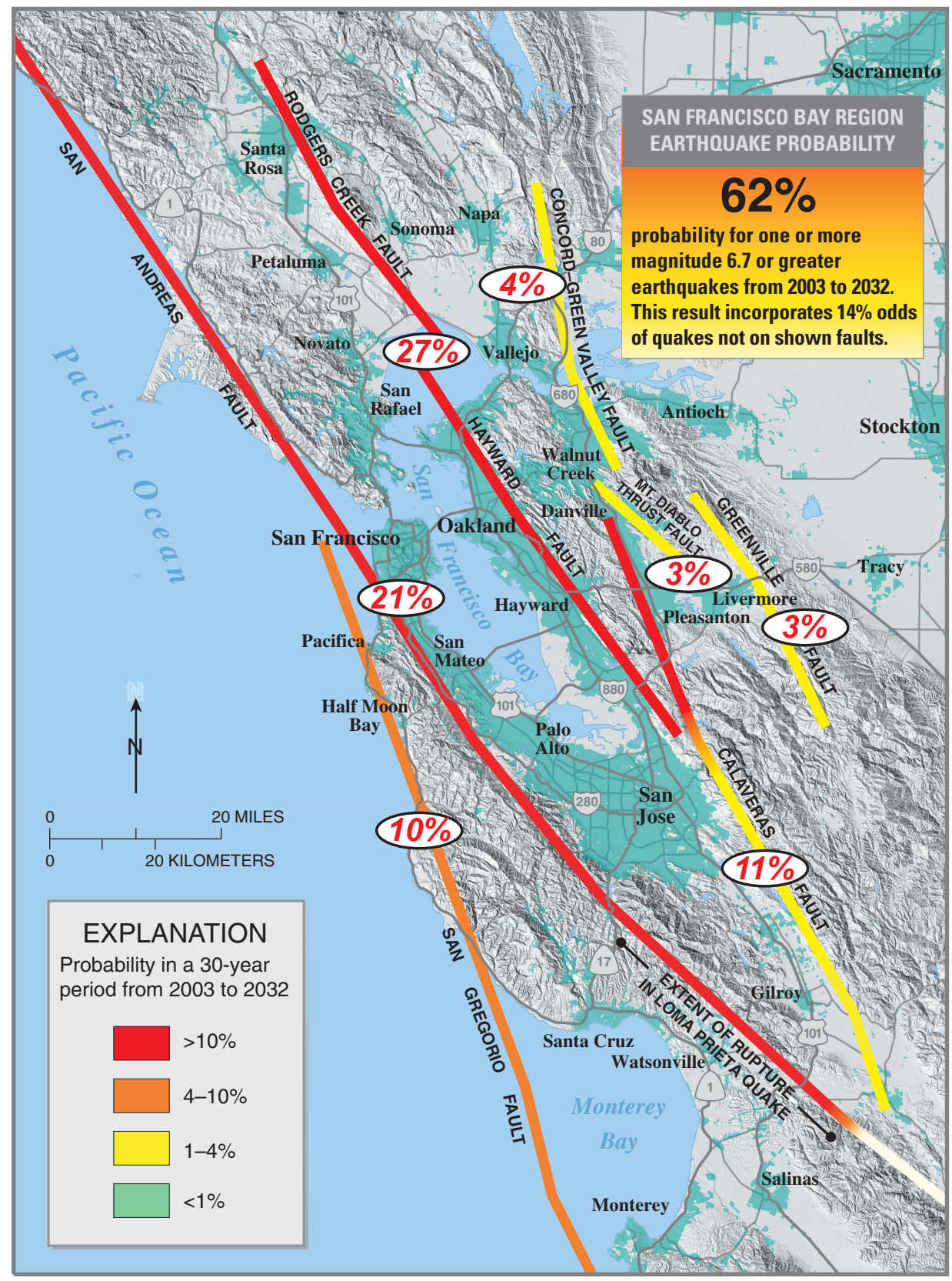

Figure 4. Probabilities (ovals) of one or more major $(M \geq 6.7)$ earthquakes on San Francisco Bay region fault systems during the next 30 yr. Likelihood varies along the length of each fault. Color indicates the probability that each fault segment will rupture in a future quake (from Working Group on California Earthquake Probabilities, 2003). 
ing the full distribution of earthquake sources and their likelihoods of occurrence. Ground motions are determined using seismic attenuation models (e.g., Boore et al., 1997) that quantify how shaking intensity decreases with distance from the fault. The nature of this relationship is a focus of on-going research as are other parameters noted in the Commission Report as influencing shaking intensity, such as the effects of local soil conditions and path effects, including amplification and trapping of seismic energy in basins.

\section{CONCLUSIONS}

It is important to remember the lessons from the 1906 earthquake and the myriad of other major urban earthquakes over the past century. These earthquakes are likely to occur without any warning. Furthermore, earthquakes do not kill people, buildings do. Even if we attain the elusive goal of short-term earthquake prediction, we are still faced with a huge inventory of existing structures and infrastructure, some of which are very vulnerable to damage and/or collapse in future earthquakes. For example, estimates suggest there will be between 150,000 and 160,000 uninhabitable households in the San Francisco Bay area following a repeat of the 1906 earthquake or a Hayward fault rupture (Association of Bay Area Governments, 2003). The situation is far worse in other parts of the world.

Earthquake forecasts alert the public to risk in high seismic hazard regions. Data from recent large earthquakes combined with advanced modeling techniques allow seismologists increasing sophistication in predicting ground motions of anticipated future quakes. Armed with the knowledge of likely ground motions, earth scientists can assist engineers in designing improved earthquake-resistant structures. We should also be working together to identify buildings and structures most at risk for severe damage and collapse in seismically vulnerable regions. Ultimately, scientists and engineers need to engage social scientists, policy makers, building owners, and the public to bring about effective seismic mitigation.

\section{ACKNOWLEDGMENTS}

Many thanks for thoughtful, helpful, and rapid reviews by Bill Ellsworth, David Schwartz, Gerry Ross, and Keith Howard.

\section{REFERENCES CITED}

Association of Bay Area Governments, 2003, Estimates of uninhabitable housing units based on earthquake scenarios issued by USGS in April 2003 http://www.abag.ca.gov/bayarea/eqmaps/ eqhouse.html.

Bakun, W.H., 1998, Scenarios for historic San Francisco Bay region earthquakes: U.S. Geological Survey Open-File Report 98-785, 14 p., http://quake. wr.usgs.gov/ bakun/OFR98-785.html.

Bakun, W.H., 1999, Seismic activity of the San Francisco Bay region: Bulletin of the Seismological Society of America, v. 89, p. 764-784.

Bakun, W.H., 2000, Seismicity of California's North Coast: Bulletin of the Seismological Society of America, v. 90, p. 797-812.

Boatwright, J., and Bundock, H., 2004, Modified Mercalli Intensity maps for the 1906 San Francisco earthquake plotted in ShakeMap format: U.S. Geological Survey Open-File Report 2005-1135, http://pubs.usgs.gov/of/2005/1135/.

Bolt, B.A., 1968, The focus of the 1906 California earthquake: Bulletin of the Seismological Society of America, v. 50, p. 457-471.

Bonilla, M.G., 1973, Trench exposure across surface fault rupture associated with San Fernando earthquake: National Oceanic and Atmospheric Administration, San Fernando, California, earthquake, of February 9, 1971: Geological and Geophysical Studies, v. 3, p. 173-182.

Boore, D.B., 1977, Strong-motion recordings of the California earthquake of April 18, 1906: Bulletin of the Seismological Society of America, v. 67 p. $561-578$.

Boore, D.M., Joyners, W.B., and Fumal, T.M., 1997, Estimation of response spectra and peak accelerations from western North American earthquakes: A summary of recent work: Seismological Research Letters, v. 66, p. 128-153.

Clark, M.M., Grantz, A., and Rubin, M., 1972, Holocene activity of the Coyote Creek Fault as recorded in sediments of Lake Cahuilla: U.S. Geological Survey Professional Paper 787, p. 112-130.

Dewey, J., and Byerly, J., 1969, The early history of seismometry-Up to 1900: Bulletin of the Seismological Society of America, v. 59, p. 193227.

Ellsworth, W.L., Lindh, A.G., Prescott, W.H., and Herd, D.G., 1981, The 1906 San Francisco earthquake and the seismic cycle: American Geophysical Union Maurice Ewing Series, p. 126-140.

Fradkin, P.L., 2005, The great earthquake and firestorms of 1906: Berkeley, University of California Press, $418 \mathrm{p}$.

Gilbert, G.K., 1884, A theory of the earthquakes of the Great Basin, with a practical application, Salt Lake City Tribune, Sept. 30, 1883 (reprint): American Journal of Science, v. 27, p. 49-53.

Gilbert, G.K., 1907, The earthquake as a natural phenomena: U.S. Geological Survey Bulletin 324, p. 1-13.

Hansen, G., and Condon, E., 1989, Denial of disaster: San Francisco, Cameron and Co., 157 p.

Harris, R., and Simpson, R.W., 1998, Suppression of large earthquakes by stress shadows: A comparison of Coulomb and rate-and-state failure: Journal of Geophysical Research, v. 103 p. 24,439-24,451, doi: 10.1029/98JB00793.

Hill, M.L., and Dibblee, T.W., 1953, San Andreas, Garlock, and Big Pine faults, California: Geological Society of America Bulletin, v. 64 p. 443-458.

Humphrey, R.L., 1907, The effects of the earthquake and fire on various structures and structural materials: U.S. Geological Survey Bulletin 324, p. 14-129.

Lawson, A.C., compiler, 1908, The California earthquake of April 18, 1906: Report of the State Earthquake Investigation Commission, vol. I: Carnegie Institution of Washington Publication 87,451 p. (Note: available today in print, http:// www.carnegieinstitutuion.org/books_in_print. html, and online, http://bancroft.berkeley.edu/ collections/earthquakeandfire/splash.html.

Lomax, A., 2005, A reanalysis of the hypocentral location and related observations for the Great 1906 California Earthquake: Bulletin of the Seismological Society of America, v. 95, p. 861-877.

Prentice, C.S., 1999, The Great San Francisco Earthquake of 1906 and subsequent evolution of ideas: Geological Society of America Special Paper 338, p. 70-85.

Reid, H.F., 1910, The mechanics of the earthquake, v. II of Lawson, A.C., chairman, The California earthquake of April 18, 1906: Report of the State Earthquake Investigation Commission: Carnegie Institution of Washington Publication 87, 192 p. (reprinted in 1969).

Richter, C.F., 1958, Elementary seismology: San Francisco, W.H. Freeman and Company, 768 p.

Sieh, K.E., 1978, Prehistoric large earthquakes produced by slip on the San Andreas fault at Pallett Creek, California: Journal of Geophysical Research, v. 83, p. 3907-3939.

Song, S., Beroza, G., and Segall, P., 2005, Evidence for supershear rupture during the 1906 San Francisco earthquake: Eos (Transactions, American Geophysical Union), v. 86, Abstract S12A-05.

Swan, F.H., Schwartz, D., and Cluff, L., 1980 , Recurrence of moderate to large earthquakes produced by surface faulting on the Wasatch Fault zone: Bulletin of the Seismological Society of America, v. 70, p. 1431-1462.

Thatcher, W., 1975, Strain accumulation and release mechanism of the 1906 San Francisco earthquake: Journal of Geophysical Research, v. 809, p. 4862-4872.

Thatcher, W., Marshall, G., and Lisowski, M., 1997, Resolution of fault slip along the $470-\mathrm{km}$ long rupture of the Great 1906 San Francisco Earthquake and its implications: Journal of Geophysical Research, v. 102, p. 5353-5367, doi: 10.1029/96JB03486.

Toppozada, T.R., and Borchardt, G., 1998, Re-evaluation of the 1836 "Hayward fault" and the 1838 San Andreas fault earthquakes: Bulletin of the Seismological Society of America, v. 88, p. 140-159.

Toppozada, T.R., Real, C.R., and Parke, D.L., 1981, Preparation of isoseismal maps and summaries of reported effects for pre-1900 California earthquakes: California Department of Conservation, Division of Mines and Geology, Open-File Report 81-11, $182 \mathrm{p}$.

Wald, D.J., Heaton, T.H., and Helmberger, D.V., 1991, Rupture model of the 1989 Loma Prieta earthquake from the inversion of strong motion and broadband teleseismic data: Bulletin of the Seismological Society of America, v. 81, p. $1540-1572$.

Wald, D.J., Kanamori, H., Helmburger, D. Heaton, T.H., 1993, Source study of the 1906 San Francisco earthquake: Bulletin of the Seismological Society of America, v. 83, p. 9811019.

Wallace, R.E., 1949, Structure of a portion of the San Andreas rift in California: Geological Society of America Bulletin, v. 60, p. 781-806.

Wallace, R.E., 1980, G.K. Gilbert's studies of faults, scarps, and earthquakes, in Yochelson, E.L. The scientific ideas of G.K. Gilbert: Geological Society of America Special Paper 183, p. 35-44.

Working Group on California Earthquake Probabilities, 2003, Earthquake probabilities in the San Francisco Bay region: 2002 to 2031: U.S. Geological Survey Open-File Report 03-214, http://geopubs.wr.usgs.gov/open-file/of03-214/.

Yu, E., and Segall, P., 1996, Slip in the 1868 Hayward earthquake from the analysis of historic triangulation data: Journal of Geophysical Research, v. 101, p. 16,101-16,118, doi: 10.1029/96JB00806.

Manuscript received 30 Jamuary 2006; accepted 7 February 2006. 